\title{
Use of Laser in the Treatment of Urethral Hemangioma
}

\author{
Yddoussalah 0*, Touzani A, Karmouni T, Elkhader K, Koutani A and Ibn Attya Andaloussi A \\ Department of Urology B, Mohamed V University, Morocco
}

Submission: January 09, 2018; Published: February 22, 2018

*Corresponding author: Othmane Yddoussalah, Department of Urology B, CHU Ibn Sina, Faculty of Medicine and Pharmacy, Mohamed V University, Rabat, Morocco, Tel: 0021268517870; Email: yddoussalah.urob@gmail.com

\begin{abstract}
We report the case of a 28-year-old man with an extensive engine of the bulbar and penile urethra, who had been evolving for 2 years and was responsible for daily urethrorrhages. A first attempt at electrocoagulation was a failure because of its intentionally incomplete nature to avoid a risk of cicatricial stenosis. Arteriographic exploration did not reveal any lesions that could benefit from embolization. It was possible to coagulate the angiomatous lesions with a side-firing laser fiber. The immediate aftermath was simple. No urethral catheter was placed postoperatively the patient resumed painless urination. A second session, 7 months later, was necessary to complete the treatment at the angiomatous urethral locations, not visible at the first session, which caused bleeding to become minimal. The decline is 6 months without recurrent bleeding. The use of the Laser therefore seems interesting in the treatment of Urethral hemangiomas.
\end{abstract}

Keywords: Hemangioma; Urethra; Laser

\section{Introduction}

The urethral localization of anhemangiomasis very rare. Responsible for urethrorrhagia and/or hemospermia, the diagnosis is easily made by endoscopy. On the other hand, the treatment remains difficult because of the localization urethral. Nous report the case of a man of 28 years treated with Laser $\mathrm{Nd}$ YAG.

\section{Case Report}

A man of 28, with no particular history, had urethrorrhages associated with initial hematuria since the age of 20 years. A first endoscopic assessment, found a single hemangiomatous lesion located in the navicular fossa that was treated by electrocoagulation. Six months later, with a greater bleeding recurrence, a new urethrocystoscopy showed the appearance of a new hemangiomatous localization extended to the ventral side of the maxillary anterior urethra in the bulbar urethra and extending to on the meatus. Arteriography was performed in search of a lesion that could be treated by embolization. This one did not find an arterial anomaly, but only a vascular puddle corresponding to the urethra at the venous time. Two years after, a new abundant urethrorrhagia, motivated an attempt of endoscopic treatment by electrocoagulation at the level of the most voluminous lesion located just under the striated sphincter. Due to the risk of secondary stenosis, coagulation was deliberately incomplete and bleeding recurrences were early.

The patient then presented daily urethrorrhages of low abundance without any repercussion or hemodynamic, nor anemia, but with a psychological and professional repercussion. 3 months later, Laser Nd YAG coagulation was performed. The procedure was performed under general anesthesia, using an SLT Side Firing fiber equipped with the 40 -watt lateral firing tip, positioned next to a cystoscope (Storz ${ }^{\circ}$ ). It was delivered 1670 Joules distributed on the lesion of the bulbar urethra and on the localization at the level of the meatus. No urethral catheterization was performed at the end of the procedure and the patient resumed spontaneous and painless urination on awakening. He was allowed to go out that same evening the urethrorrhagia disappeared for a month, to reappear but with lesser amounts.

A second laser coagulation session was performed 6 months later. During the endoscopy, it was found that previously treated lesions had not recurred, but that the Hemangioma had a new, more distal location in the bulbar urethra (Figure 1). This one was treated with the same modalities by delivering 1400 Joules on the bulbar lesion mainly at 4 and 8 hours. A slight retraction of the mucosa during coagulation and no induced bleeding was observed (Figure 2 \& 3). 6 months, all urethrorrhagia disappeared and the quality of the jet is perfect. 


\section{Global Journal of Reproductive Medicine}

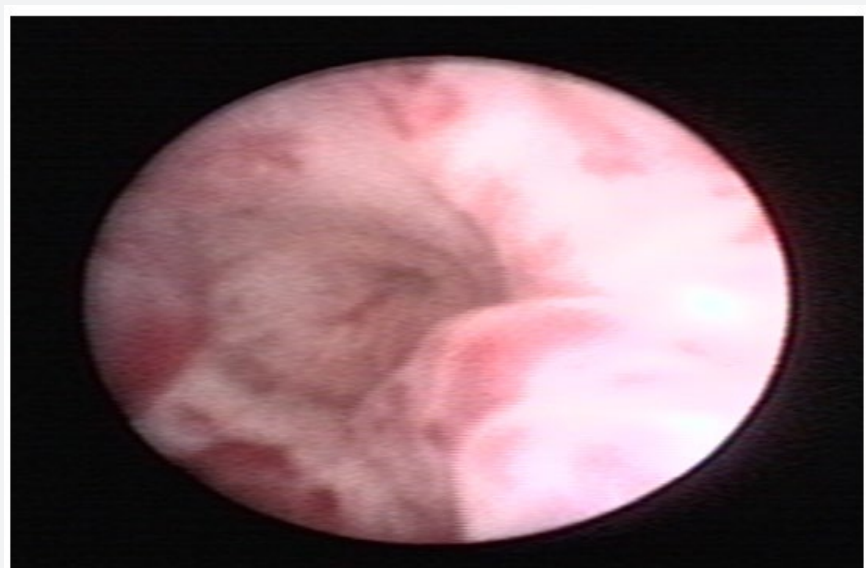

Figure 1: Urethroscopic view of the bulbar urethra: the mucosa is lined with an extensive angioma.

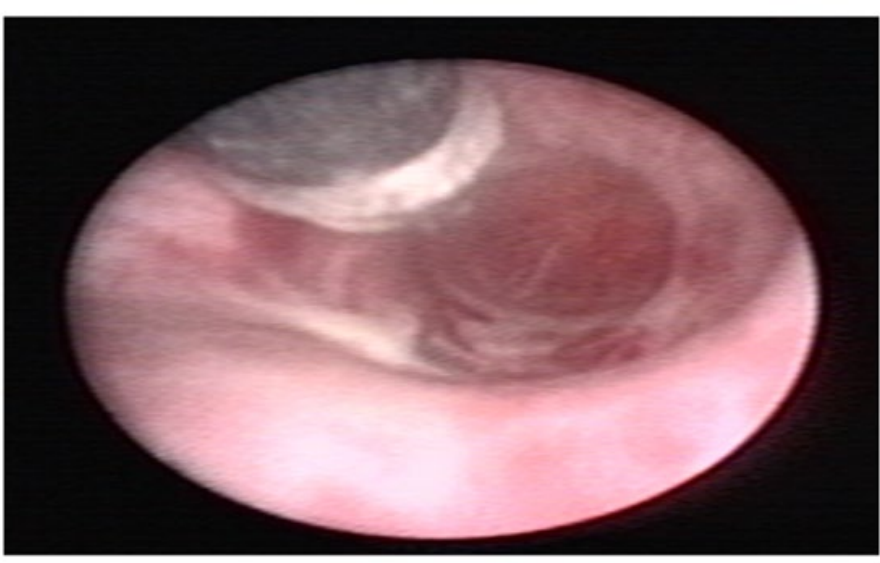

Figure 2: Photocoagulation of the angioma by a side-firing laser fiber

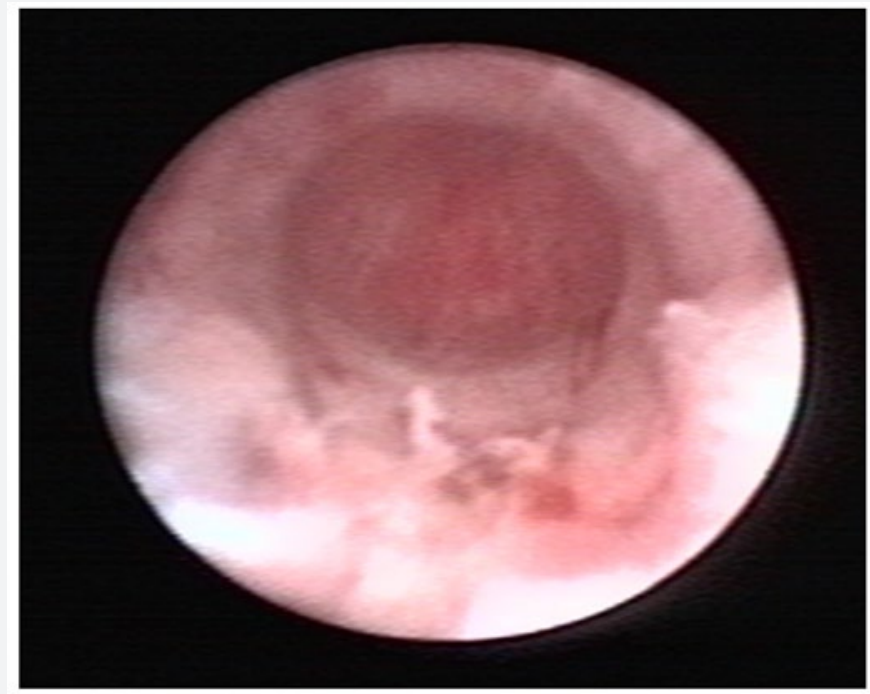

Figure 3: endoscopic vision of the bulbar urethra after photocoagulation by the laser. 


\section{Global Journal of Reproductive Medicine}

\section{Discussion}

The location of a Urethral hemangiomas is very rare. They can be localized polypoid rather in the posterior urethra [1-4], the most often reported from, because the source of difficulties of treatment and responsible for the most important bleeding, differs by a diffuse attack of all the anterior urethra starting from the bulbous urethra to the meatus [5-8]. The clinical symptomatology is dominated by bleeding: urethrorrhagia or macroscopic hematuria and in adult hemospermia [9]. Cases in pediatrics suggest a congenital origin $[2,10,11,8]$, but even in adults the symptoms sometimes go back to childhood [12]. In a 42-year-old man, a posttraumatic etiology was evoked in front of a posterior urethral lesion [1]. The presence of scrotal skin lesions or on the glans is possible, even in the context of angiomatous disease (Klipper-Weber syndrome) [13,14]. The diagnosis is based on endoscopy. Recall that even in children a neoplastic etiology must be excluded formally, in particular a rabdomyosarcoma [2]. Apart from the rare case of the localized lesion of the meatus whose surgical excision is easily performed $[10,11,4]$, the therapeutic management of extensive lesions is difficult: many methods have been tried.

Complete surgical excision followed by reconstruction is cumbersome and causes complications Radiotherapy, attempted many years ago, is not very effective and dangerous $[15,16]$. The practice of endo-urethral instillations resulted in stenosis only. The possibility of embolizing angiomatous lesions after a vascular opacification can sometimes lead to healing [6], but is not always possible. In infants, systemic corticosteroid treatment was able to reduce the lesions [17]. Endoscopic methods are more suitable. Endoscopically controlled injection sclerotherapy has been successful, but sometimes at the cost of iterative scans and stenos $[5,13]$. Electrocoagulation is effective but with a still significant risk of secondary stenosis. The use of the Laser $\mathrm{Nd}$ YAG is interesting since the photocoagulation in liquid medium acts in surface area of 1 to $2 \mathrm{~mm}$ of depth with a less risk of inducing a secondary stenosis [18-21]. In children, the size of the urethra renders any endoscopic treatment very delicate and requires appropriate equipment [22].

\section{Conclusion}

The urethral localization of a hemangioma is rare and its treatment is not yet codified. In children, thanks to a thin endoscope and the use of laser, endoscopic treatment seems possible effectively, without secondary stenosis.

\section{Consent of Patients}

Written informed consent was obtained from the patient's next of kin for publication of this case report and any accompanying images. A copy of the written consent is available for review by the Editor-in-Chief of this journal.

\section{Authors Contributions}

O. Yddoussalah wrote the manuscript. All authors read and approved the final manuscript.

\section{References}

1. Hayashi T, Igarashi K, Sekine H (1997) Urethral hemangioma: case report. J Urol 158: 539-540.

2. Crankson SJ, Abdul-Aaly M, Hugosson C, Ahmed S (1992) Haemangiomatous polyp of the posterior urethra in a boy. Pediatr Radiol: 22(1): 74-75.

3. Parshad S, Yadav SP, Arora B (2001) Urethral hemangioma. An unusual cause of hematuria. Urol Int 66(1): 43-45.

4. Sharma SK, Reddy MJ, Joshi VV, Bapna BC (1981) Capillary haemangioma of male urethra. Br J Urol Jun 53(3): 277.

5. Bissada NK, Frangos DN, Ferentzi C (1994) Management of extensive urethral hemangiomas with endoscopic sclerotherapy: case report. J Urol 151: 1015-1016.

6. Roberts JW, Devine JC (1983) Urethral hemangioma: treatment by total excision and grafting. J Urol 129(5): 1053-1054.

7. Steinhardt G, Perlmutter A (1987) Urethral hemangioma. J Urol 137(1): 116-117.

8. Tilak GH (1967) Multiple hemangiomas of the male urethra--treatment by Denis Browne-Swinney-Johanson urethroplasty. J Urol 97(1): 96-97.

9. Furuya S, Ogura H, Tanaka Y, Tsukamoto T, Isomura H (1997) Hemangioma of the prostatic urethra: hematospermia and massive postejaculation hematuria with clot retention. Into J Urol 4(5): 524526.

10. Manuel ES, Seery WH, Cole T (1977) Capillary hemangioma of the male urethra: case report with literature review. J Urol 117(6): 804.

11. Sauvage P, Miclo S, François JM, Vetter JM, Yamagushi K (1980) Angioma of the male urethra. Chir Pediatr 21: 133-135.

12. Murray WJ, Fletcher MS, Walters HL, Packham DA (1986) Treatment of urethral hemangioma by selective arterial embolization. J Urol 136(6): 1304-1306.

13. Kardar A, Sundin T, Linjawi TA (1994) Urethral hemangioma managed with sclera therapy case report. Scand J Urol Nephrol 28(4): 435-437.

14. Maeda KA (1984) Successful case of urethral reconstruction in a child with persistent urethral bleeding due to an extensive cavernous haemangioma. Br J Plats Surg 37(4): 536-538.

15. Fernandes E, Manivel JC, Gonzales R (1990) Urethral hemangioma in childhood: treatment by total excision and single-stage urethroplasty. Pediatr Surg Int 5(3): 218-220.

16. McCrea LE (1948) Angioma of male urethra: Review of the literature and report of a case. Urol \& Cutan Rev 52: 204

17. Cook CL, Sanfilippo JS, Verdi GD, Pietsch JB (1989) Capillary hemangioma of the vagina and urethra in a child: response to shortterm steroid therapy. Obstet Gynecol 73(5 Pt 2): 883-885.

18. Destito A, Sasso F, Valentini AL, Sentinelli S, Grassetti F (1985) Considération sur un cas rare de tumeur hémangiomateuse de lurèthre postérieur, A rare case of hemangiomatous tumor of the posterior urethra. Ann Urol(Paris) 19(6): 406-408.

19. Hernando BJ, Pavon ME (1996) Argon laser treatment of urethral angioma. Report of the first case. Arch Esp Urol 49(8): 859-861.

20. Khaitan A, Hemal AK (2000) Urethral hemangioma: laser treatment. Int Urol Nephrol 32(2): 285-286. 
21. Landthaler M Hohenleutner U (1990) Laser treatment of congenital vascular malformations. Int Angiol 9(3): 208-213.
22. Lauvetz RW, Malek RS, Husmann DA (1996) Treatment of extensive urethral hemangioma with KTP/532 laser. Lasers Surg Med 18(1): 9295.

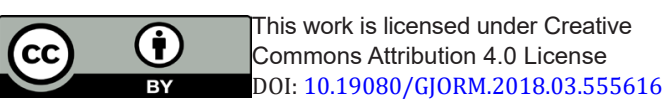

\section{Your next submission with Juniper Publishers will reach you the below assets}

- Quality Editorial service

- Swift Peer Review

- Reprints availability

- E-prints Service

- Manuscript Podcast for convenient understanding

- Global attainment for your research

- Manuscript accessibility in different formats ( Pdf, E-pub, Full Text, Audio)

- Unceasing customer service

Track the below URL for one-step submission https://juniperpublishers.com/online-submission.php 